\title{
広範囲に発症し両下肢麻痺を呈した骨結核の一例
}

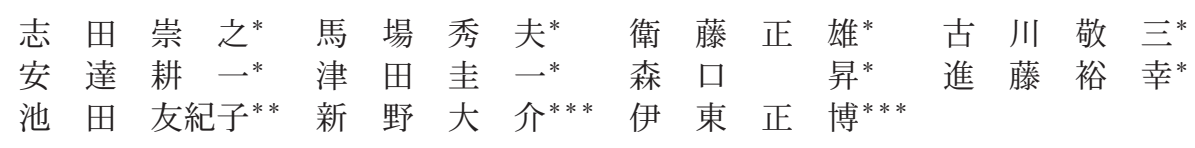

\section{A Case of Multiple Bone Tuberculosis with Bilateral Lower-Leg Paralysis}

Takayuki Shida*, Hideo Baba*, Masao Eto*, Keizo Furukawa*,

Koichi Adachi*, Keiichi Tsuda*, Noboru Moriguchi*, Hiroyuki Shindo*, Yukiko Ikeda**, Daisuke Shinno***, and Masahiro Ito***

症例は 29 歳男性. 14 ヶ月前より頸背部痛，腰痛が出現．近医外来にて加療したが症状軽快せず，総合 病院入院. 頸椎から仙椎にかけての多発する溶骨性変化, Th1/2，3/4，7 の硬膜外膿瘍および腸骨，肋 骨に溶骨性変化を認めた。骨生検にて乾酪性肉芽腫，ラングハンス巨細胞，抗酸菌を認めたことから多発 性骨結核と診断され，抗結核薬の内服を開始したが，内服加療開始後より Th4 以下のしびれが出現し， 両下肢不全麻痺を呈した。約 6 ケ月間の抗結核薬内服と卧位安静加療を行ったが麻痺の十分な改善が得ら れなかったため当科入院. Th3 4 亿認めた膿場が硬膜管を圧排しており, 後方よりインストゥルメンテー ションを使用した 7 椎間におよぶ脊椎固定術, 骨移植術を施行し, 症状の著明な改善を得た. 術後 4 ケ月 で再発兆候はなく, 独歩も可能となった。 今回我々は, 病変が極めて広範囲である稀な骨結核の 1 例を経 験したので若干の文献的考察を加えて報告する.

A 29 year-old man first noticed cervical, back, and lumber pain 14 months ago. He was admitted to general hospital for further examination, and was diagnosed with multiple bone tuberculosis. Though medication was started, loss of sensation below Th4 and bilateral lower leg paralysis increased. After six-months of medication, he was admitted to our hospital. We performed operation with the use of posterior instrumentation and bone graft, and achieved significant improvement. Four months after operation, he achieved full leg strength. In this paper, we report the above case and discuss multiple bone tuberculosis, referring to previous literature.

Key words : multiple bone tuberculosis (多発性骨結核), tuberculosis of spine (春椎カリエス), bilateral leg paralysis (両下肢麻痺)

は じめに

日本での結核患者の発生数は 1950 年以後減少傾向 にあるが, 結核は依然として決して見落としてはなら ない疾患であり, 早期の診断・治療によって, 重篤な 合併症を来さないことが重要である。 今回我々は広範 囲に発症し, 両下肢麻痺を呈した稀な骨結核の 1 例を 経験したので若干の文献的考察を加えて報告する.

\begin{abstract}
症
例

症例：29歳 男性 インドネシア人

主訴 : 歩行困難

既往歴・家族歴：特記事項なし

現病歴：入国後（当科入院 14 ヶ月前）より頝部痛, 腰背部痛が出現. 鎮痛剂内服, ブロック注射などの加 療を行うも症状改善せず総合病院入院. 画像所見, 腸 骨からの骨生検所見から骨結核と診断された．６ヶ月
\end{abstract}

\footnotetext{
* 長崎大学整形外科 Department of Orthopaedic Surgery, Nagasaki University, Nagasaki, Japan

** 長崎医療センター内科 Department of Internal Medicine, Nagasaki Medical Center, Nagasaki, Japan

*** 長崎医療センター病理 Department of Pathology, Nagasaki Medical Center, Nagasaki, Japan
} 
前より抗結核剤 4 剂併用による内服加療を開始（開始 後 2 ケ月から 1 剂追加投与し 5 剂併用）した. 炎症所 見および $39^{\circ} \mathrm{C}$ から $40^{\circ} \mathrm{C}$ 台の発熱は内服開始時より徐々 に改善したが, 内服加療開始後にもかかわらず Th4 以下の知覚低下, 両下肢麻㽻が出現し徐々に増強. 5 ケ月前より自力歩行不能となった. 6 ケ月間の抗結 核剂内服加療後も両下肢麻痺症状の改善は認めず, 手 術目的で当科紹介入院となった.

神経学的所見：MMT では両下肢とも筋力低下（右 下肢優位）を認め, 歩行は不能であった. Th10 以下 には $5 / 10$ の知覚低下があり, 排尿障害（頻尿・開始 遅延）もみられた。深部腱反射は上下肢とも両側六進 しており, バビンスキー反射, 膝クローヌスも両側陽 性であった.

画像所見; 単純 X 線所見では胸腰椎椎体に溶骨性 変化があり（図 1), 単純 CT では $\mathrm{C} 4,6, \mathrm{Th} 1,3,4$, 7，8，10，L1，2 に多発する溶骨性変化を認めた. C4, Th1, Th3, Th7, Th10, L1 椎体では特に溶骨 性変化が高度であった（図 2)，MRI でも CT 同様, 多椎体に骨破壊像を認め, 造影 MRI では Th1/2, $3 / 4,7$ の椎体・硬膜外腔に rim enhancement $\left.{ }^{6}\right)$ があ り, 膿瘍または炎症性肉芽の存在が疑われた（図 3 ). 脊椎以外には骨シンチで左肋骨に多発集積像を, 腹部 CT では右腸骨に溶骨性変化を認めた（図 4).

腸骨骨生検所見; H.E. 染色ではラングハンス巨細 胞, 乾酪性壊死, 抗酸菌染色では抗酸菌を認めた（図 $5)$.

臨床検查所見：白血球の増加は認めず， CRP ・ 血 沈は軽度上昇を認めた。ツベルクリン反応は直径 $12 \mathrm{~mm}$ の中等度陽性であった。喀痰培養, 喀痰の PCR では結核菌は検出されなかった.

経過；内服加療にもかかわらず両下肢麻痺は改善を 認めなかったため, 手術適応と考え手術を行った。手 術は椎弓切除後, C6 から Th6 の instrumentation を 使用した後方固定を行った. ロッドの固定にはテクミ ロンテープも併用した，皮下，筋層内，硬膜外腔には 膿瘍形成は認められなかった。術後は SOMI 装具を 装着し，1 ケ月後にソフトカラー，３ ケ月後にカラー フリーとした．術後経過は良好であった，術後 3 週よ り歩行器歩行, 術後 4 週では自力排尿, 杖歩行が可能 となり, 母国へ帰国した術後 4 ケ月の時点では独歩も 可能となった. JOA score（日本整形外科学会頸䯣

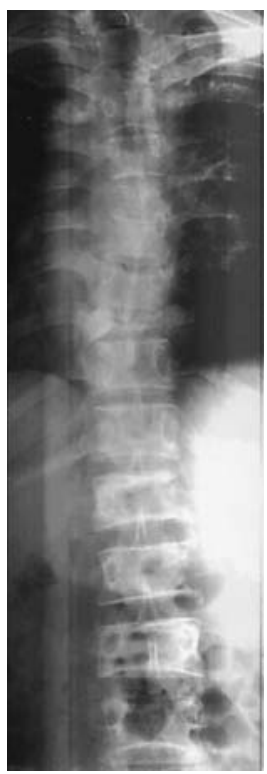

a

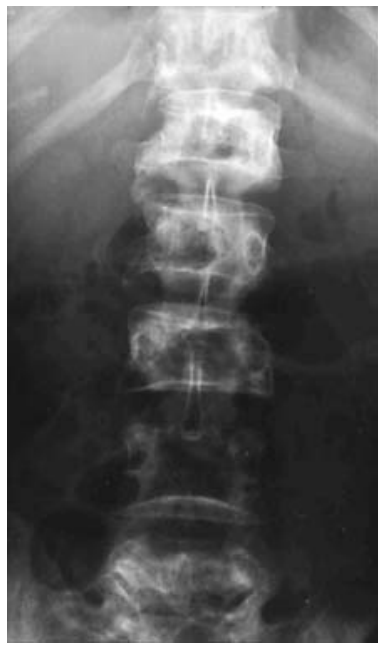

c

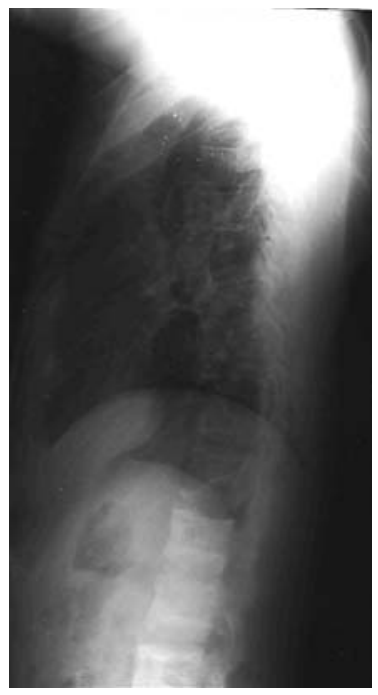

b

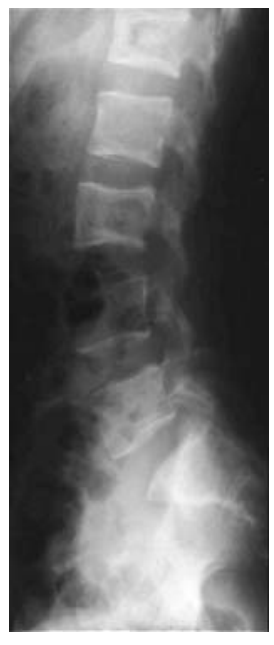

d
図1 単純 $\mathrm{X}$ 線像

a 胸椎正面 b 胸椎側面 c 腰椎正面

d 腰椎側面

多発する溶骨性変化を認める.

症治療成績判定基準のうち, 上肢 2 項目を除いた 11 点満点とした）は術前の 3.5 点から 9.5 点と著明に改 善した. 


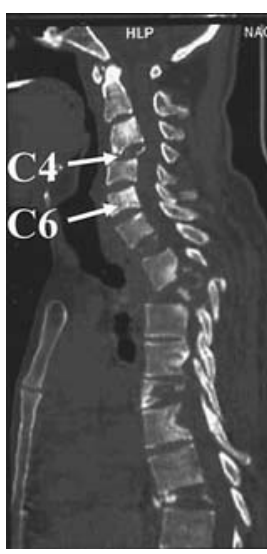

a

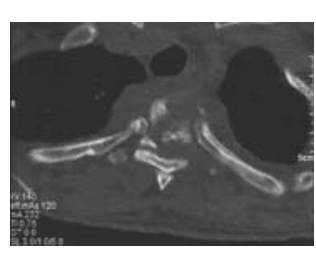

$\mathrm{c}$

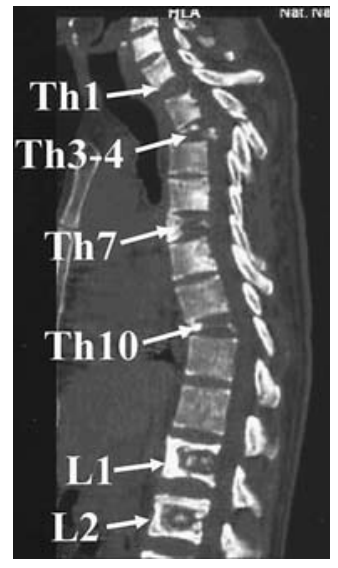

b

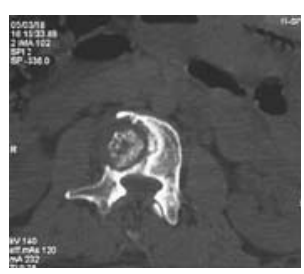

d
図 2 単純 $\mathrm{CT}$ 像

a 頸椎矢状断 b 胸腰椎矢状断 $\mathrm{c} \quad \mathrm{Th} 3$ 水 平断 $\mathrm{d} \quad \mathrm{L} 1$ 水平断

頸椎, 胸椎, 腰椎に多発する溶骨性変化および 骨枢形成を認める。
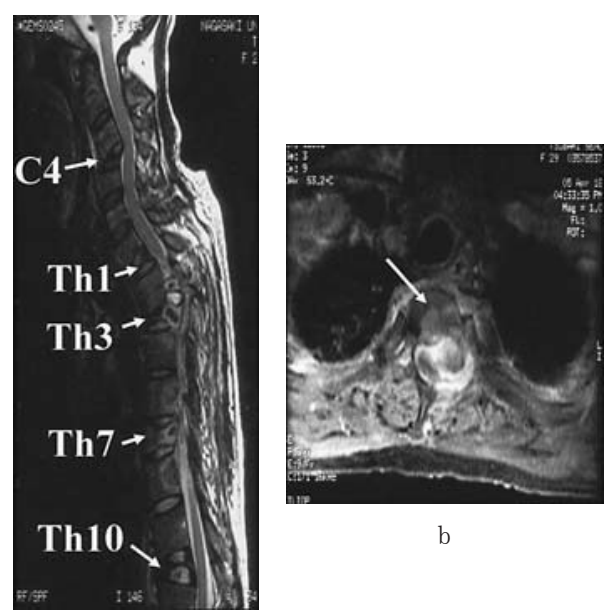

a

図 3 MRI 像

a 頸胸椎 $\mathrm{T} 2$ 強調 矢状断 $\mathrm{b} \quad \mathrm{Th} 1 / 2$ 造影 MRI 水平断

多発する溶骨性変化および椎体・硬膜外腔に rim enhancement を認める

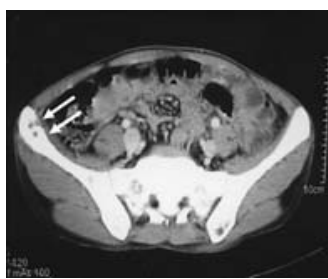

a

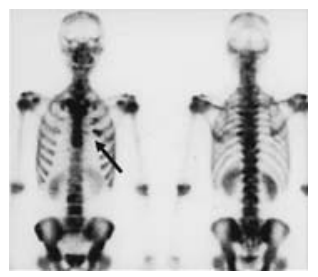

b
図 4 a 腹部 CT $\mathrm{b}$ 骨シンチ 腹部 CT にて右腸骨に, 骨シンチにて左胁骨に 骨病変（溶骨性変化）を認める

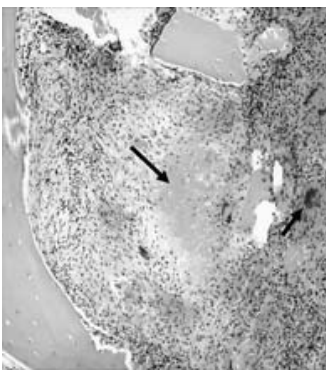

a

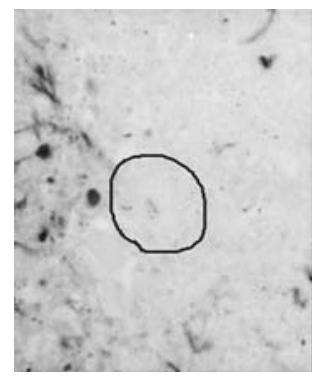

b
図 5 病理所見

a H.E.染色 b 抗酸菌染色

乾酪性肉芽腫やラングハンス巨細胞, 抗酸菌の 存在を認める

考察

日本での骨結核患者数は 1978 年が 1626 人, 1997 年以降は 500 ～ 700 人程度と横ばいである ${ }^{1)}$ (図 6). 結核予防会研究所による「結核の統計」によると, 2005 年の日本での結核患者数は約 28000 人であり, 減少傾向にあるとはいえ患者数は決して少ないわけで はない，また，患者母国での結核患者数は 2005 年が 62 万 5 千人で日本の約 22 倍と報告されている. 海外 渡航者の増加による日本での骨結核患者数は今後も増 えることが予想され，東南アジア出身の患者は特に,

日常診療において結核を発症していないか常に念頭に 置く必要がある.

脊椎は骨結核のうち最も発生頻度が高い部位であり, 鑑別疾患としては化膿性脊椎炎, サルコイドーシス, 転移性骨腫瘍, 悪性リンパ腫, 変形性脊椎症などがあ る. 画像所見の特徵として, MRI で椎体周囲の膿瘍 形成を認めること ${ }^{4}$ や， CT での骨殹(破壊された椎体 


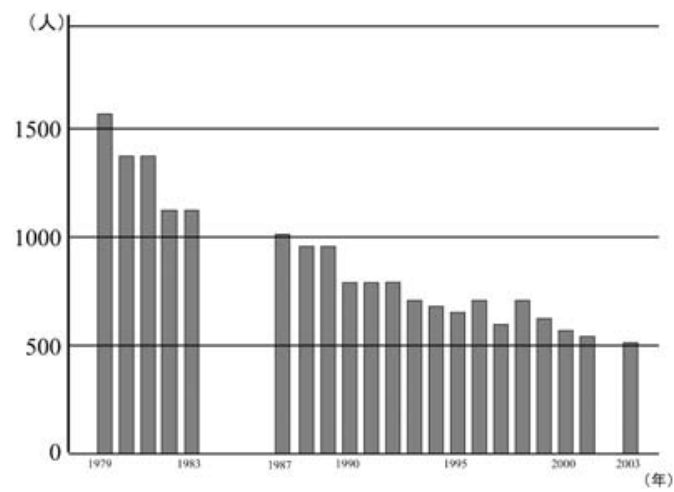

図 6 骨結核患者数の推移 (人/年) 1983 年から 1987 年, 2002 年, 2004 年以降は データがなく空白とした.

内肉芽組織に認める石灰化) 形成 ${ }^{6)}$ などがあげられ， 確定診断としては喀痰培養や PCR 法, 膿培養による 菌の存在を認めることとされている ${ }^{1)}$ が, 培養や PCR 法によって菌が証明されないことも多い吕. 本症 例でも MRI 上の膿瘍形成や骨殹は見られたが，PCR 法，培養検査などは全て陰性であった，培養検査や PCR 法が陰性であっても多発する例 ${ }^{6)}$ の報告もあり, 日常診療では注意が必要である.

本症例は罹患 17 椎体と広範囲で, さらに腸骨や肋 骨にも病変を認めたが, このように椎体に著明な溶骨 性変化を伴って広範囲に発生する脊椎カリエスの症例 は極めて稀である. 今回我々が検索できた過去 10 年 間の脊椎カリエスの報告例では, 10 椎体以上の報告 例は力丸ら ${ }^{8)}$ の 37 例の報告で 1 例（罹患 13 椎体）の みであった. 今回の症例は入国直後に発症しており,
母国で感染した可能性が高い．東南アジア出身者の脊 椎カリエスでは広範囲に著明な溶骨性変化を伴って発 症する可能性があり, 高度な麻痺が出現しないか注意 深く観察し，他部位にも発症していないか広範囲に精 査を行う必要があるものと思われた.

$$
\text { ま と め }
$$

(1)極めて広範囲におよぶ稀な骨結核症例を経験し， 手術により著明な下肢麻痺改善を得た.

(2)渡航者の増加に伴い日本での骨結核患者は今後増 加することが予測され，高度な麻痺が出現しないか注 意深く観察し, 他部位にも発症していないか広範囲に 精査を行う必要があるものと思われた.

\section{参 考 文 献}

1）藤田正樹ら：最近の脊椎カリエスについて．臨床整形 外科, 38(3): 293-300, 2003.

2) 岸 和彦ら：結核性脊椎炎一最近の傾向と対策. 脊椎 脊髄, 15(7)：745-749, 2002.

3）松永智美ら：広範な骨欠損と腸腰筋膿瘍を伴った多椎 間脊椎カリエスの 1 例。整形外科, 57 (3)：279-282, 2006.

4）水溜正也ら：結核性脊椎炎に対する instrumentation の術後成績について. 西日本脊椎研究会誌, 29(1)：115117, 2003.

5）小野哲男ら：最近の脊椎結核の動向。西日本脊椎研究 会誌, $11: 32-35,1985$.

6) 斉藤正史, 石川雅之：結核性脊椎炎. 春椎春髄, 14 (6)： 604-607, 2001.

7）柴崎啓一：春椎カリエス今昔. 整形・災害外科，46 : 621-627, 2003.

8）力丸俊一, 芝啓一郎：脊椎力リエスおよび化膿性脊椎 炎に対する instrumentation surgery. MB Orthop., $9(6): 87-100,1996$. 